УдК $316.346 .2: 781.6$

MALONE K.

\title{
«HER STORIES UNSUNG»: \\ EMBEDDING FEMINIST ACTIVISM FOR SOCIAL CHANGE WITHIN MUSICAL COMPOSITION FOR CONCERT HALL PROGRAMMING
}

Anglo-American composer Kevin Malone wrote "Her Stories Unsung", a collection of feminist piano pieces, between 2013 and 2016 as a comment on women's inequality in patriarchal societies and as a call for action to change the status quo through both concert hall programming and a new means of composition which is gender-aware or gender-specific. As a displaced artist, K. Malone became aware of how marginalised groups in societies are exposed to different types of oppression and inequality. Drawing upon material from USA, UK and Ukraine, K. Malone worked with Argentinian concert pianist Diana Lopszyc to create socio-political music which requires theatrical actions during performances of the music with specific attention drawn to the gender of the performer according the various programmatic narratives within the music. These narratives are drawn from key aspects of the lives of Lilith (the Biblical pre-Eve woman), Ada Lovelace, Julia Pastrana, Emmeline Pankhurst and Delia Derbyshire. K. Malone's visually-informed gender coding of his concert music and its performance establishes a departure from the attempted (but never successful) norm of gender-neutral interpretation of purportedly gender-neutral concert music. In this way, K. Malone calls upon composers and performers to align their talents with activists who strive for social change to achieve gender equality but, in doing so, to ensure that the integrity of the musical art work (which currently is still inflected by patriarchy) be rigorous yet entertaining.

Keywords: feminism, concert music, piano music, socio-political music, the atricality, gender, equality, activism, suffrage, Kevin Malone's music.

Mrs Pankhurst, the leader of the Women's Social and Political Union, was arrested in London yesterday. In effect, she is charged with having "feloniously counselled and procured certain persons whose names are unknown" to commit the bomb outrage last week at Mr Lloyd George's unoccupied house... The Home Office authorities have for some days had under consideration the speech delivered by Mrs Pankhurst at Cardiff on Wednesday, the night following the bomb outrage. In this speech Mrs Pankhurst recalled that... "I told them that I was prepared to accept responsibility for all acts to which women felt themselves driven... . I have incited; I have conspired; and I say this - that the authorities need not look for the women who have done what they did last night, I accept responsibility for it. If tomorrow I am arrested for what happened and sent to penal servitude, I shall prove in my own person that the punishment cannot be carried out. If they send me for 5 years, 10 years, or 20 years, I shall not stay. I shall at once hunger strike. If they torture me with force-feeding, that cannot last very long; they cannot keep me alive very long; and they will have to let me die or let me go. If I drop out of the fight hundreds will take my place"1.

${ }^{1}$ Mrs Pankhurst Arrested. Manchester Guardian, 25 February 1913. Available at : www.theguardian.com/theguardian/1913/feb/25/greatspeeches (Accessed: 16.09.2017). 
Emmeline Pankhurst was rallying about women's rights - particularly the right to vote - following decades of silence from the British Parliament. She eventually called for direct action - including illegal and dangerous action - to embed a basic human right into a stubborn patriarchal system. 1918 saw a partial victory which allowed a subset of the female population to vote, and by 1928, British women had gained full voting equality with men.

How might this process be represented in piano music?

The Genesis of " Her Stories Unsung"

I composed this collection of dramatised feminist piano pieces between 2013 and 2016. The research concerns gender-bias regarding the first (pre-Eve) woman, Lilith, Ada Lovelace, Julia Pastrana, Emmeline Pankhurst and Delia Derbyshire. Each piece explores an aspect of how women are marginalised through a chosen historical (and, with Lilith, mythical) figure, as well as exploring new, marginalised or seldom-used techniques of piano playing. The duration is 25 minutes.

Originally from the United States, I lived alone in Paris from 1980 to 1981 during which time I felt what it was like to be a displaced person. I considered how this would be expressed in music: the feeling of being mentally somewhere else in opposition to where I was physically present, a feeling of not belonging. I moved back to the USA a changed person, and emigrated to the UK in 1985 to develop a life in composition. Once again I was a foreigner, but I was able to live happily as a partial outsider, viewing culture and tradition through a lens fashioned from wilful displacement. I began to explore feministpolitical music by Laurie Anderson and patriarchal system within the field of Music. What stood out most were wider, global issues of social injustice, and in particular, what must be the most widespread of all injustices: gender inequality, which intentionally targets half of the human population.

In May 2013, I met Eva Lopszyc, Professor of Composition at the Manuel de Falla Conservatory in Buenos Aires, Argentina, at the "Premieres of the Season" Festival in Kiev. She suggested that I compose a new work for her sister, Diana Lopsycz, Professor of Keyboard at the conservatory. At the time, I was working on a full-length Mark Twain opera called "Mysterious 44" which involved research into Biblical characters and their unjustifiable actions, including oppression of women. The idea to compose "Lilith" was proposed to D. Lopszyc, with an understanding that we should consider the work gendered.

I stopped working on the opera and wrote "Lilith", the name of the first woman created by the Abrahamic god, the woman who predated Eve. The story in Genesis chapter 1, verse 27 tells of how females, which would include Lilith, was fashioned at the same time as Adam and from the same substance, and, therefore, was equal to him. But Adam did not appreciate an equal partnership according to various narrative interpretations in The Torah and Talmud, and so Lilith was banished from Eden, and Eve was created from Adam's rib according to Genesis chapter 2, verse 22.

"Lilith" was premiered by D. Lopszyc at La Scala, Buenos Aires on 26 November 2013. I continued research regarding injustice to women, and completed the first collection of " Her Stories Unsung" which was premiered by D. Lopszyc at the Cosmo Rodewald Concert Hall, Manchester UK on 4 February 2016, with a second performance on a 19thC piano at Elizabeth Gaskell's House, the former residence of the Victorian novelist, in Manchester on 6 February.

There are three specific cultures which ground the sounds and sensibilities of this music: American (my place of birth), British (my place of residence) and Ukrainian (a 
frequent place in my travels). Other cultural musics are suggested through pentatonic pitch collections and synthetic modes, especially those with a lowered 2nd scale degree.

Embedded within "Lilith" and throughout the entire collection is a fragment of Ukrainian popular music frequently broadcast across Kiev's Independence Square (as I heard it named) in 1993 and 1994. I never discovered the title of this melancholy tune, but I did notate it and found it to be a useful template on which to experiment with different styles. (All but the last three notes also happen to be the opening melody of Donald Fagen's 1982 song "Maxine").

Figure 1. Ukrainian melody broadcast in Independence Square, Kiev 1993 \& 1994

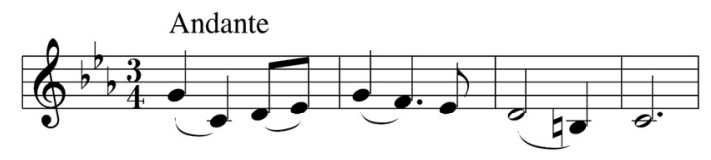

A Call to Musical Arms

"Her Stories Unsung" has a visual element with socio-political purpose: to be outward-facing, openly calling for social change through synchronised stimulation of both visual and aural senses in the concert hall, to make the musical performance as watchable as it is listenable. Thus the musical collection presents to the (captive) concert hall audience an additional active mode of engaging with concert music: that of seeing as a part of the music, not just seeing as a part of the performance.

The watchable actions were devised as to ensure their full and necessary integration into the physical realisation of performing the sound of the music. In some cases, there is even a sense of "watching" sound itself - not just pianistic physicality included for the sake of a theatrical idea (something I explored in "Count Me In" from 2005 in which the pianist parodies voting corruption in the USA, UK and Ukraine from 2000-2005 by crawling under the piano to avoid detection).

This approach is not allied to concept music associated with John Cage, happening music akin to Allan Kaprow, or danger music by or for Dick Higgins. It is not connected to the Fluxus movement, intermedia or interdisciplinary arts. While these variably-important experiments and artistic areas often draw much attention to physicality of performance and the body in particular, it is usually seen that the body's corporeality is the substance of the work. What is not evident in musical works within these cross-boundary areas is how the gender and gender experiences of the performer inform the creation, performance and reception of the works.

Such intentional visual stimulus in "Her Stories Unsung" forces the audience to have to watch, to objectify the pianist - and the pianist's gender - as the visual embodiment of the score, and not just be a deliverer of the music. The audience's gaze is required, the pianist's corporeal presence is called to attention, and therefore the gender of the performer is kept at the forefront of the listeners-turned-spectators.

At its core, "Her Stories Unsung" asks for the act of performing it to be informed by the performer's gender experiences. In the first instance, the titles of the individual pieces are all named after women, which raises the question of how a male pianist might approach interpreting such a piece. Would a male pianist's interpretation sound conciliatory, patronising, detached, empathic, over-compensating? How might a female pianist's interpretation come across: sympathetic, lecture-some, insightful, (too) political?

Second, the physicality of realising the music in each piece requires the audience's gaze, and thus the range of performing from normal piano touch to hand and arm clusters, 
scraping the keys, knocking on the piano case and restraining the hands while performing vividly illustrate the pianist's body as a vessel full of experiences which is burning calories for the benefit of the audience, despite facing intrusions and obstructions both technical and social.

In his programme notes for "De Staat" Louis Andriessen states: "Many composers feel that the act of composing is suprasocial. I don't agree. How you arrange your musical material, what you do with it, the techniques you use, the instruments you score for, all of this is determined to a large extent by your own social circumstances, your eduction, environment and listening experience and the availability - or non-availability - of symphony orchestra and government grants. The only point on which I agree with the liberal idealists is that abstract musical material - pitch, duration, rhythm - is suprasocial. It is part of nature. There is no such thing as fascist dominant seventh"1.

Musical sounds on their own - that is, without associating certain sounds with images or symbols or applying semantic rule sets through repeated reinforcement (eg ii V - I) - are incapable of expressing anything other than themselves. This is, of course, what I. Stravinsky clarified when he initially stated in 1936, "I consider music, by its nature, incapable of expressing anything"2. Therefore, when we hear so-called political music by D. Shostakovich, it is anything but political, but rather a series of pre-labeled symbolic musical sounds assembled in different orders to relate rather familiar narratives. (Peter Kivy's account of music as imitation, illustration and representation delineates this attachment of symbols from abstractly expressive music in "Sound and Semblance".)

The attempted effectiveness of such music is wholly reliant on the establishment of a fixed and taught musicianship, the imposition of metaphoric symbols upon the musical sounds, the reinforcement of those rule-sets upon musicians and their audiences, and the ordering and re-ordering of those sounds with occasional reminders of the extra-musical meanings attached to those sounds. Music as just music could never be political.

However, the programming of a "political" symphony is only political through its programming, not its innate sound. In the act of programming a concert, a few people decide to impose upon the musicians and the audience a particular group of pieces. In many cases, the musicians have no say in the matter (if they are under contract to perform), and audience members with subscription tickets may be paying for music they do not want to hear. The repertoire is vastly flooded with music by male composers, and so programmers who remain unconscious about this fall prey to political patriarchy, while those who are aware make political gender choices which then affects the composers' public profile as well as affecting the musicians and audience. And then the act of performing programmed music becomes part of the socio-political process, especially if a conductor is involved.

The history of musical repertoire is massively overshadowed by men. The history of the ownership of concert halls, orchestras, financial institutions, instrument manufacturing and sales, etc. was (and is) lorded over by men. The entire infrastructure is gendered. The incorporation of female musicians - the highest level within the patriarchal structure - was to provide the actuation of male composers' music: women-workers (performers) were to mechanically realise the creative vision of the men-composers. The process is almost invariably overseen by the in situ male supervisor: the conductor.

\footnotetext{
${ }^{1}$ Andriessen, L. (1994). "De Staat". (1976). London : Boosey \& Hawkes.

2 Stravinsky, I. (1936). Chronicle of My Life. London : W. Gollancz, 91-92.
} 
But what if the musical score itself calls for socio-political acts to be performed as an integral part of making the music itself? Louis Andriessen's "Workers Union" (1975) requires a group of willing performers to play almost-continuous unison phrases in moderately fast semiquaver rhythms while improvising the pitches to make a continual aggressive sound, as though at a political rally over at least a 20 minute duration. In his programme notes L. Andriessen states: "Workers Union was originally written for the orchestra De Volharding (Perseverance).... This piece is a combination of individual freedom and severe discipline: its rhythm is exactly fixed; the pitch, on the other hand, is indicated only approximately, on a single-lined stave. It is difficult to play in an ensemble and to remain in step, similar to organising and carrying out political actions"1.

Similar passages of exhausting fast unison phrases occur in Andriessen's "De Staat" (1976), and this demand upon musicians is taken to extreme in Frederick Rzewski's "Les moutons de Panurge" (1969) where each musician has to slowly accelerate an additive series of notes (one note, then two notes, then three notes, etc. until 65 notes are strung together, and then continue with the reverse process by subtracting the first note, then the second note, etc.) in absolute unison regarding pitch, dynamic and rhythmic. In all three of these examples, the audience realises the musicians are under strain due to the demands of the musical requirement to stay synchronised despite increasing fatigue.

The success of each performance of "Workers Union", "De Staat" and "Les moutons de Panurge" exposes the amount of practice each musician and the ensemble have undertaken before going in front of an audience, and their ongoing levels of concentration of the music being performed, and this exposure of individual responsibility in the service of group action is the point of the execution of these works in front of an audience. The physical realisation of each of works into musical sound for each performance is a tangible political act.

"Her Stories Unsung" as symbolic and actual socio-political music.

Lilith was the ur-woman, without any sisterhood or maternal examples. How should she act, what should she feel, and who is that only other person, Adam?

Cast in two sections, "Lilith" undergoes constantly faltering attempts at self-styling womanhood (constant collage of sharply-contrasted styles mercurially juxtaposed against each other) until she is banished, deprived of human contact for having been born with and demanding to maintain - equality (set as an extensive coda reliably adhering to a single style).

Lilith searches for a style to give her a voice to her situation. The music gallops through 19thC Romanticism, French Impressionism, ragtime, rock, pop, jazz, filmic melodrama pastiche, Pacific Asian pentatonic fragments, the Ukrainian popular tune cited earlier, pseudo free improvisation, the 13thC Dies Irae melody, and combinations of the above distorted through brutal hand/arm clusters roughly outlining melodic contours. See Figure 2. Given the absence of a single style or the integration of several related styles, the musical content is heard as being about style itself. (This is akin to V. Silvestrov's 1977 "Kitsch Music", where style precedes the composing of the musical which is brought into being for the sake of the chosen style having a body in which to exist.)

${ }^{1}$ Andriessen, L. (2002)."Workers Union" (1975). Amsterdam : Donemus. 
Figure 2. Malone, K. (2013). Her Stories Unsung. Composers Edition, 1-3.

Opening juxtaposed styles of "Lilith", bars 1-38

for Diana Lopszyc
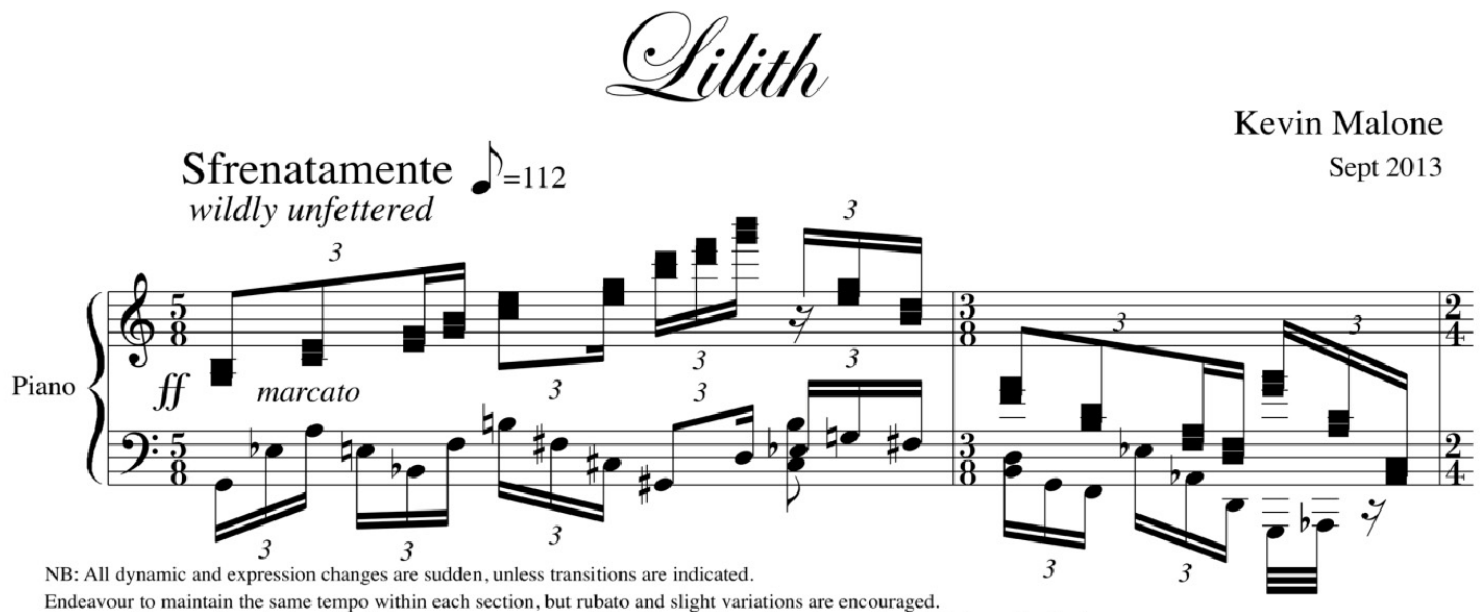

Sept 2013

Clusters without accidentals should include as many notes as possible. Those with accidentals must be all-black or all-white keys.
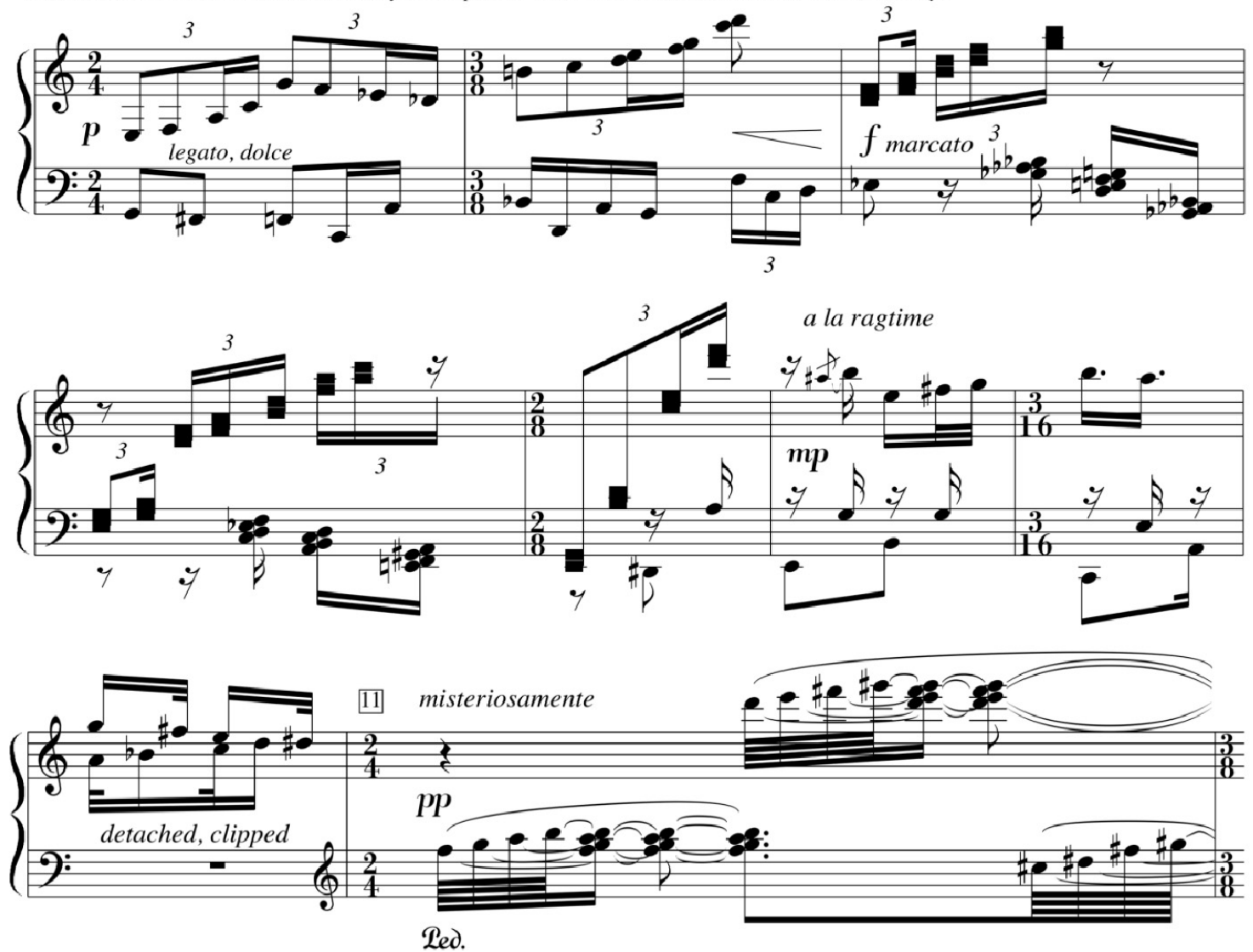

The anxiety and confusion which permeates "Lilith" suddenly cease with the Coda, the banishment section. Here, a single style - a lullaby - oversees Lilith's isolation. See Figure 3. The melody "Bicycle Built for Two" (H. Dacre, 1892) is thickened with gentle hand clusters with occasional pentatonic homophony, and accompanied by a slow-picked quasi-guitar bass line set an augmented fourth apart from the melody. The familiar descending melodic contour on the words "Daisy, Daisy, Give me your answer, do" 
suggests a grounding of the former anxiety and bitter-sweet resignation to the lowered status which Lilith and her progeny would eternally endure. The lyric also gives the floral name "Daisy" to Lilith (who will subsequently be relegated to the role of a sexually dangerous she-devil in later scriptural writings). Finally, the use of this musical quotation refers to the emasculated computer HAL 9000 in the film "2001: A Space Odyssey" (Kubrick, 1968) when it sings "Daisy, Daisy..." during a dismantling procedure which destroys its self-identity, and diminishes its role to that of unquestioning servitude.

Figure 3. Malone, K. (2013). Her Stories Unsung. Composers Edition, 14.Lullaby as coda in "Lilith", bars 157-164
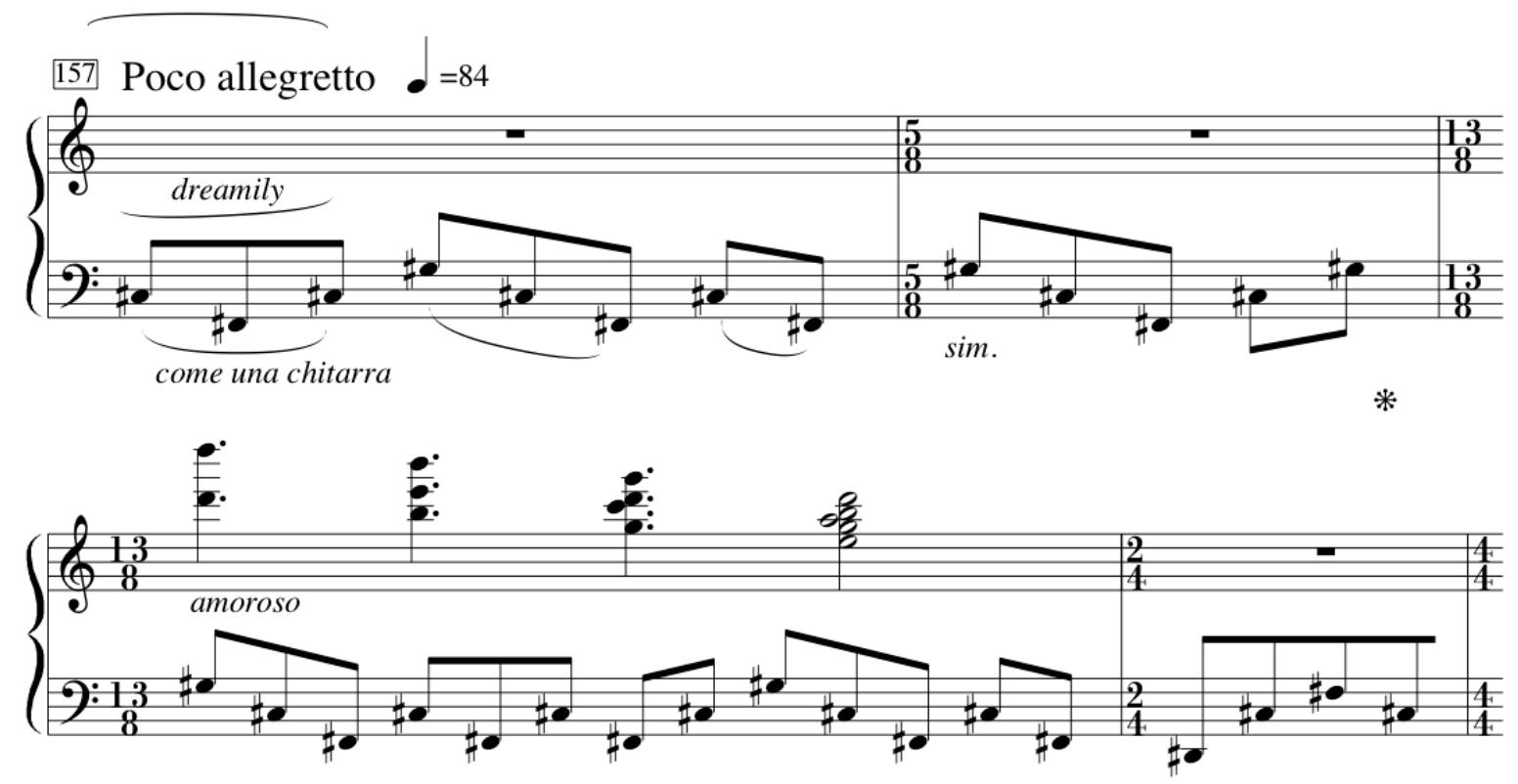

Led.

* $\operatorname{Ted}$.
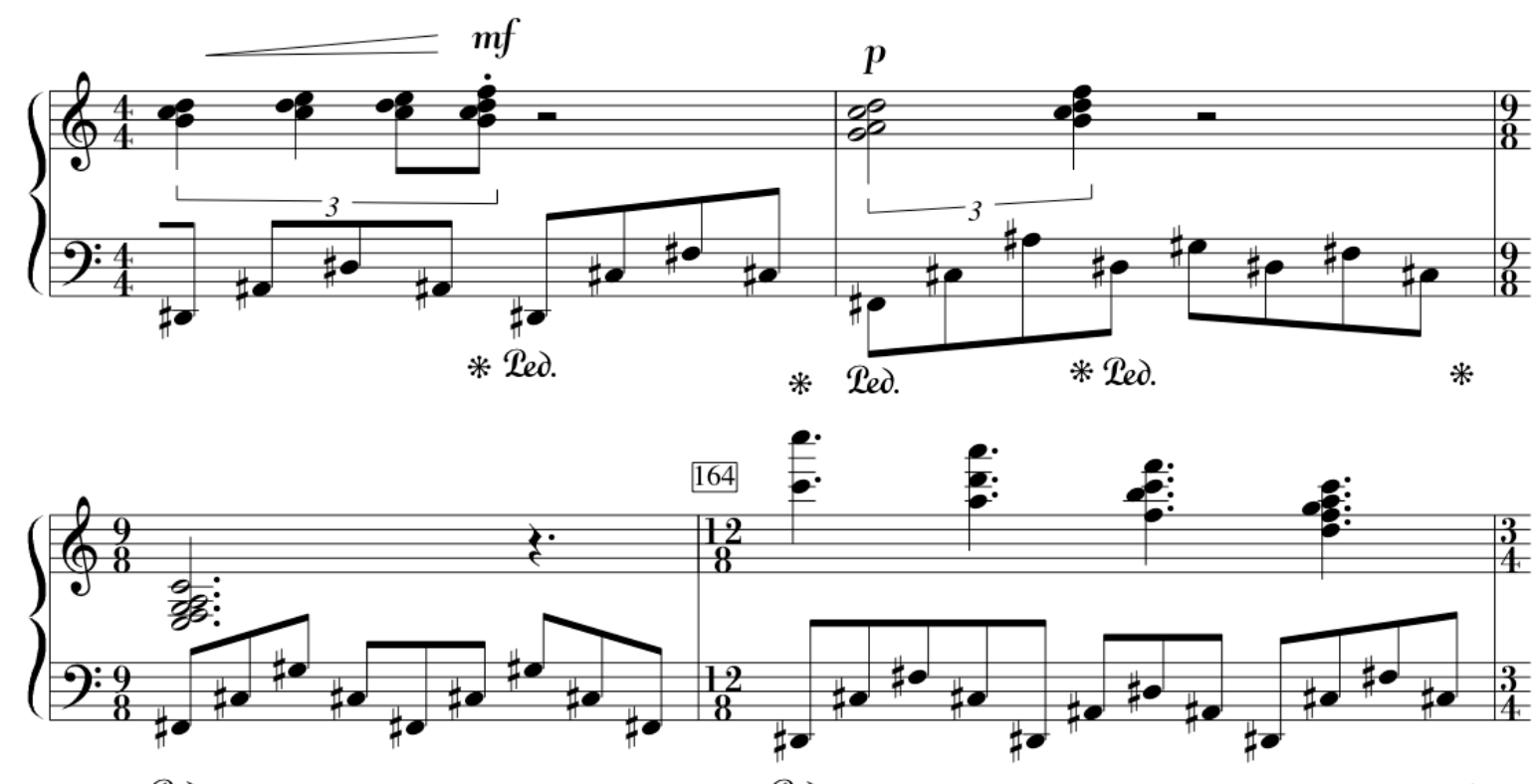

Led.

* Ted.

* 
Lilith's identity, too, had been destroyed. She was forcibly displaced, her equality revoked. The pianist opens with aggressive palm clusters - a dramatic and visually aggressive action - only to ultimately withdraw to consonant fingered clusters which are mirrored in the gentle action of the pianist's arm motion.

This programme of angry rebellion and resignation sets up the rest of the pieces in the "Her Stories" collection. The depictions of women which follow each draw musical fragments from "Lilith", utilising new physical techniques embedded within the composition's development.

Ada Lovelace (1815-1852 UK) was the first person to write computer programs, or to be more precise, to create the complete series of instructions which would run an infinite number of procedures on a calculating machine. Had the computer - or, "analytical engine" which was designed by her husband Charles Babbage - actually been built, Lovelace's program would have been the procedure to put it into motion.

"Ada Lovelace" explores not only the precision of her mathematical mind, but also the fact that she played the piano and was part of the Byron family of artists. She was a polymath: a programmer, musician, and intellectual hostess in a formidably maledominated milieu. The music juggles these contrasting aspects of Lovelace's life into a whirlwind toccata of machine-like sounds which includes fragments from Stravinsky's "The Rite of Spring" and Schumann's "By the Fireside" ("Scenes from Childhood") and "Traumes Wirren" (Fantasy Piece, op.12). See Figure 4.

Figure 4: Malone, K. (2016). Her Stories Unsung. Composers Edition, 19. "Ada Lovelace" bars 2745 with I. Stravinsky and R. Schumann quotations
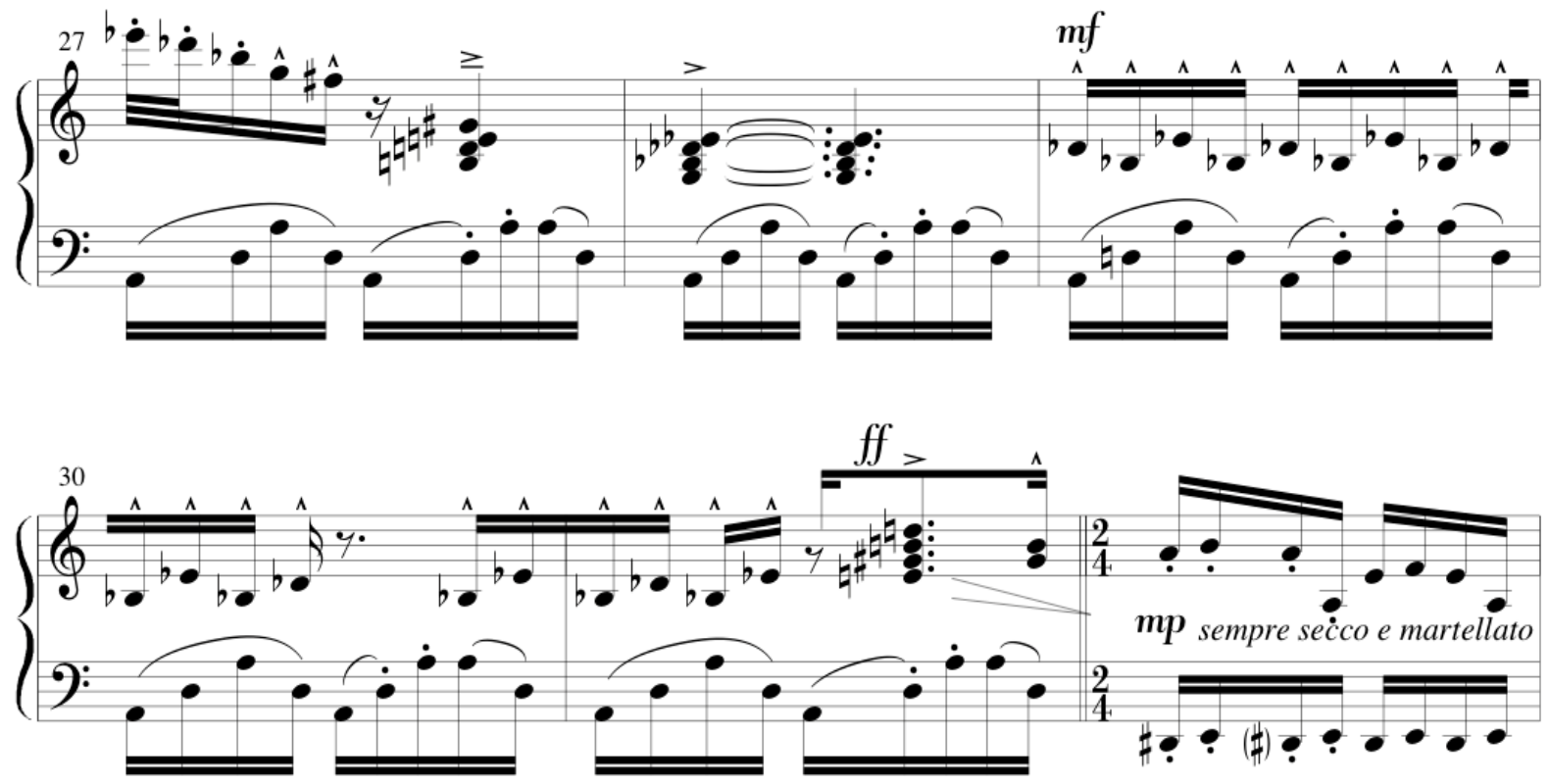

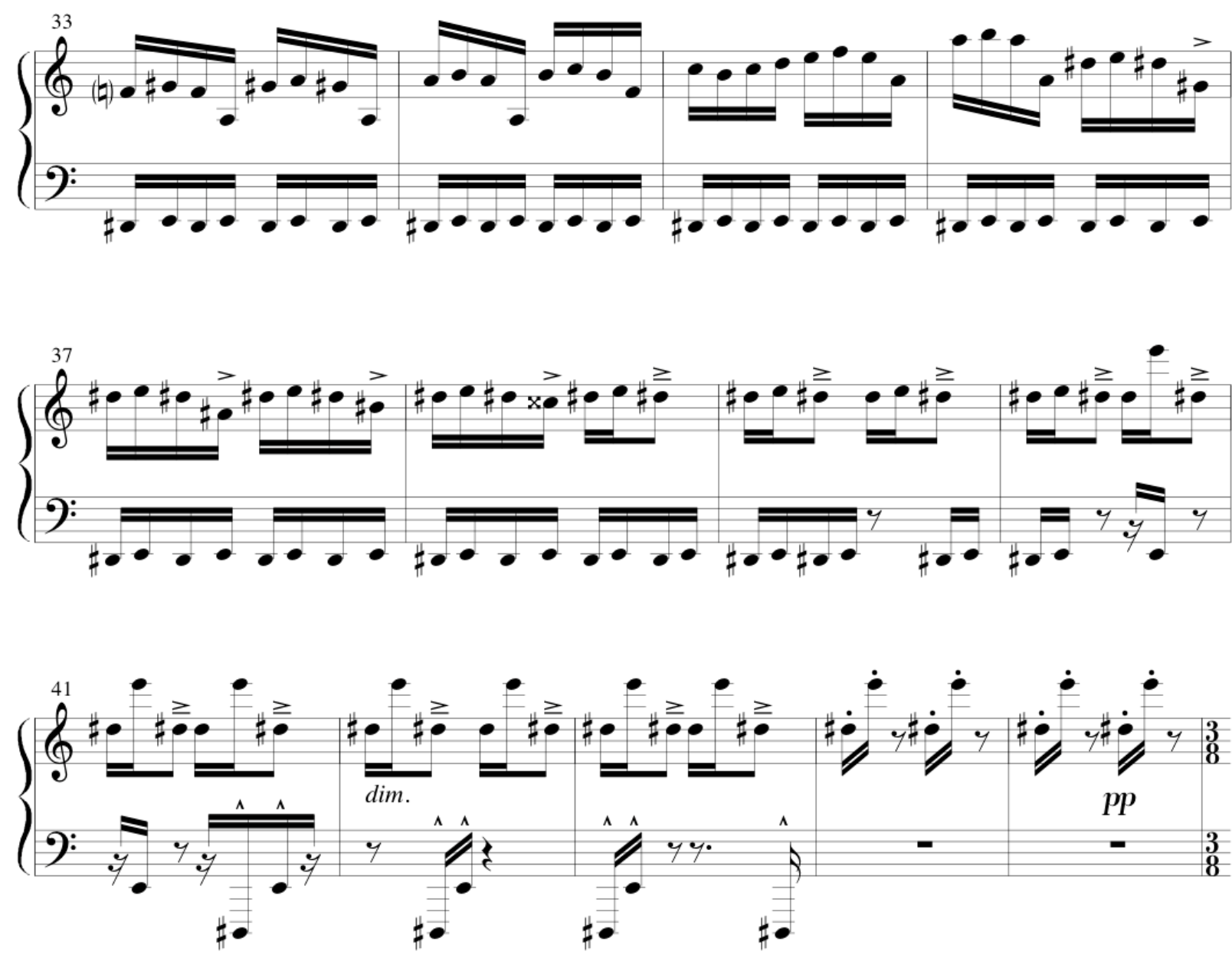

Babbage's computer concept was static (a drawing of mechanical device in an inactive state), whereas Lovelace's programs were active: sequences of events, temporal actions, akin to the notation which represents a composition. Thus, "Ada Lovelace" is a program (notated score) which puts into service the device (the piano) to which it is applied. The music's opening section "powers up" the piano, the gears are meshed, and then the coded program punched on paper - represented by the pianist as a stiff card scraped atop the keys - is loaded and the complex calculations begin. (E. Reilly notes that not only were 2othC computer programs stored on stacks of punched cards, but in the early 18thC programmed weaving looms were invented, which by 1800 were fully automated by Jacquard to weave patterned textiles according to coded punched paper ${ }^{1}$ ).

The gender of the pianist would affect the interpretation of this piece. Understanding that the music is about computer instructions and with the score marked "meccanico, eccentrico" and "Toccata preciso", a male perspective might be to treat this as a "program": neatly execute the notation using the piano. In contrast, a female interpretor might see this as a "programme": the struggle to be taken as equal in a patriarchal

\footnotetext{
${ }^{1}$ Reilly, E. (2003). Milestones in Computer Science and Information Technology. Westport, Conn. :
} Greenwood Press, 145. 
environment by not only inventing (computer) programs, but also performing as hostess, pianist and intellectual, the results of which would be closely scrutinised - and criticised by men. This would be exacerbated by the fact that all of the piano music she performed (executing the notation using the piano) would be by male composers ${ }^{1}$ (with Clara Schumann lurking in the shadows), with the added irony that the music of "Ada Lovelace" also contains a quote from "The Augurs of Sprin - Dance of Young Maidens" which exhibits both I. Stravinsky's motor rhythms and the ballet's narrative of the portending of a young woman to be chosen for sacrifice to appease the (male) gods. "Ada Lovelace" draws upon "Lilith" 's jazz-influenced strings of unresolved dominant seventh harmonies, cluster chords and simultaneously playing the piano's two extreme registers.

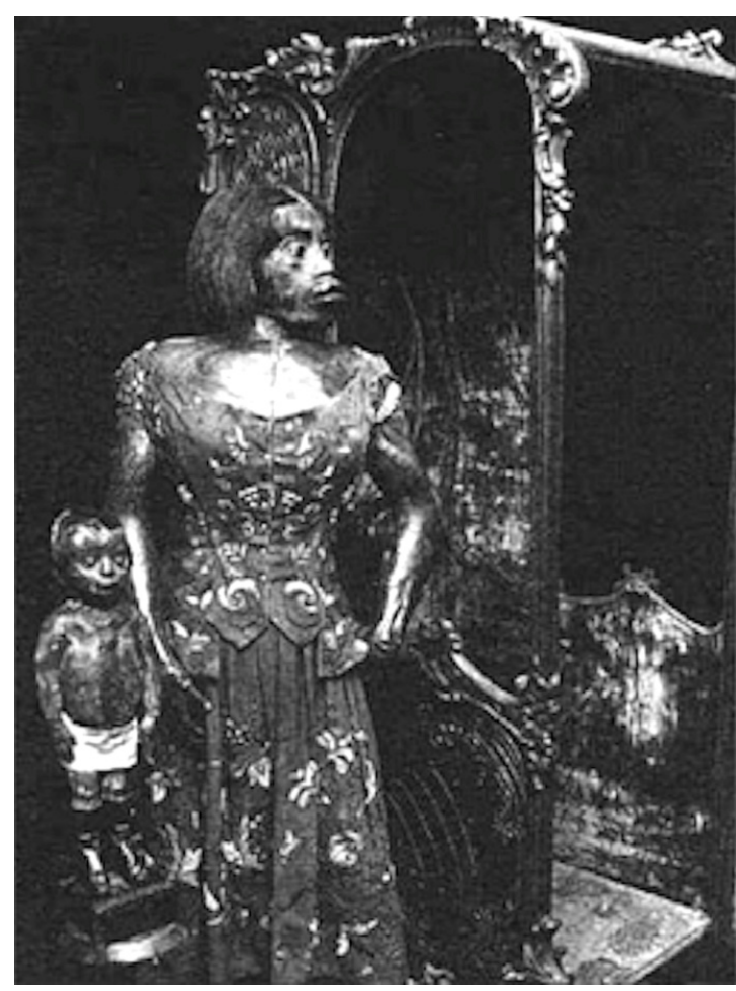

Figure 5. Photograph (date unknown) of J. Pastrana and child mummified for exhibition ${ }^{2}$

Julia Pastrana (1834 Mexico-186o Russia) lived much of her life in a 19thC travelling exhibition, being displayed for her condition of hypertrichosis - exceptional hairiness - and for her exaggerated facial shapes suggestive of apeor bear-like features. Marrying her exhibitor and bearing their child, she died at the age of 25 as a result of the birth. Her husband continued to exhibit her and their son (who also died a few days after birth) by mummifying their bodies in Moscow, thereby continuing his source of income. When the novelty of this wore off, their bodies were unceremoniously discarded. J. Pastrana's body eventually turned up in Norway where it was kept as a scientific specimen for 90 years. In 2013, her remains were buried in a religious funeral in Mexico, her homeland. See Figure 5 .

"Le tombeau de Julia Pastrana" simultaneously inhabits two worlds - life and death - by drawing upon the bimodal and pentatonic aspects of "Lilith" 's lullaby coda. Indeed, this is an extended lullaby for J. Pastrana, although much of it is unsettled by rumbling trills on both the keyboard's low register and the body of the piano itself, which also is knocked upon by the knuckles. All musical materials are paired and cast in opposition to each other: sustaining trills versus decaying chords, pitched sound versus wooden

${ }^{1}$ And yet, R. Schumann distinguishes F. Schubert from L. Beethoven when he stated: "Schubert is a more feminine character compared to the other [Beethoven]; far more loquacious, softer, broader" (Schumann, R. (1946). On Music and Musicians. Ed. Konrad Wolff, trans. Paul Rosenfeld. New York : Pantheon, 116).

${ }^{2}$ Anon. (1970). Photograph of the mummies of Julia and her son taken when they were exhibited in Malmo, Sweden, in January 1970. Cited in Licsc, J.B. and Miles, A.E.W. (1993), Julia Pastrana, the nondescript: An example of congenital, generalized hypertrichosis terminalis with gingival hyperplasia. American Journal of Medical Genetics 47, 198-212.

ISSN 0130-5298. Українське музикознавство. 2017. Вип.: 43 
noise, intervals grouped as semitones and thirds versus perfect fourths, phrases of steadyduration rhythms versus outbursts of ornaments and unsteady rhythms.

While women and men with exceptionally unusual physical features have been exploited - John (Joseph) Merrick, the "Elephant Man", is often cited when referring to Victorian "freak shows" (D. Lynch 1980) - the activity of viewing the human body for personal pleasure is an intrusion experienced by most women on a daily basis, although sometimes it may be difficult to acknowledge because it is normalised by patriarchal societies with widespread exploitation in broadcast and print media. In most competitive performances, women are encouraged to wear as little as possible in order to display their bodies (eg "Miss Universe" contests).

J. Pastrana's ongoing incarceration (and voicelessness) was initially social through her disfigurement, then in marriage to her employer, and then in death through the spectacle of mummification, at which point the male tendency of objectification had reached its fullest expression. John Shepherd states, "As reflections of the male desire to control the world, women themselves must be controlled and manipulated. This is accomplished by means of their isolation and objectification....In order to become 'successful' in a male-dominated society, they must package themselves (or be packaged, as in advertising images) as objects amenable to control by men... . The existence of music, like the existence of women, is potentially threatening to men to the extent that it (sonically) insists on the social relatedness of human worlds..."1.

Although not as extreme, a female pianist will be subjected to the audience's gaze differently from that of a male pianist. Men usually wear black and white - and certainly do not have their shoulders exposed - while women wear comparatively less fabric and usually have some colour as part of the garment. Therefore, how women use their body with regard to their actual flesh is seen differently: exposed arms - and sometimes exposed shoulders and legs or even just ankles - suggest a different intimacy with the piano and the performativity of the music.

With this in mind, "Le tombeau de Julia Pastrana" seeks a sisterhood with female pianists: like J. Pastrana, the pianist is subjected to the audience's gender-biased gaze as an exhibition. Regarding the sound-producing activity of knocking and trilling on the piano body, the female pianist may consider this to be touching the large, darkened object which J. Pastrana became, although other pianists may treat these actions as rapping on a coffin (which J. Pastrana did not have until 153 years after her death) or simply as extended sonic/pianistic techniques.

Emmeline Pankhurst (1858-1928 UK) was the founder of the Women's Social and Political Union in 1903 in Manchester, UK which campaigned exclusively for the right for women to vote in Great Britain. She was savvy when using the social media of her day news papers and photography - knowing that her "Deeds, not Words" suffrage campaign would draw attention by being physical, performative - not verbal - in its expression. Marches held by the WSPU (also called The Suffragettes) featured all of its women wearing long white dresses which would stand out in newspaper photographs. Eventually its activities extended into breaking windows and arson in attempts to have British Parliament pass laws to allow women to vote. Pankhurst was imprisoned for her criminal

${ }^{1}$ Shepherd, J. (1987). Music and Male Hegemony. Music and Society: The Politics of Composition, Performance and Reception. Cambridge, 154. 
deeds and chose to perform a hunger-strike to gain publicity for the WSPU. During her imprisonment, she was painfully force-fed food through tubes in her nose and mouth.

In "Emmeline Pankhurst (Her Victorian musical transgressions and punishments)", the music is ragtime, the new, jaunty, confident music of Pankhurst's era. Brutal interjections from "Lilith" 's loud passages and repetitive triple fortissimo multiple octaves on the pitch $\mathrm{D}$ disrupt the savvy ragtime campaign. When these crude attempts to shout down the campaign fail, the music assuredly increases its performative flair by shifting to the theme from No. 24 of Paganini's 24 Caprices for Violin. Consequently, the pianist faces physical, not verbal, assault: the keyboard lid is slowly closed by the left hand while the right hand attempts to maintain virtuosic flair, but fails. When the campaign is restarted, mockery (distorted contrapuntal imitation) joins another keyboard lid assault. Switching to a new, softer tactic via the Ukrainian popular tune, the pianist's left arm is forced to stretch across difficult register changes. Several more attempts to campaign result in the arms completely crossed (as though tied), and the keyboard lid kept closed. When freed, the hands continue playing on top of the closed keyboard lid, until the left hand pulls the right hand off the lid. In defiance, the pianist loudly hums the rest of the notated music through pinched lips, insisting that the (musical) voice will be heard without the violence of forcing a different substance (food) into the body. See Figure 6.

Figure 6. Malone, K. (2016). Her Stories Unsung. Composers Edition, 40-42."Emmeline Pankhurst" various disruptions, bars 110-134
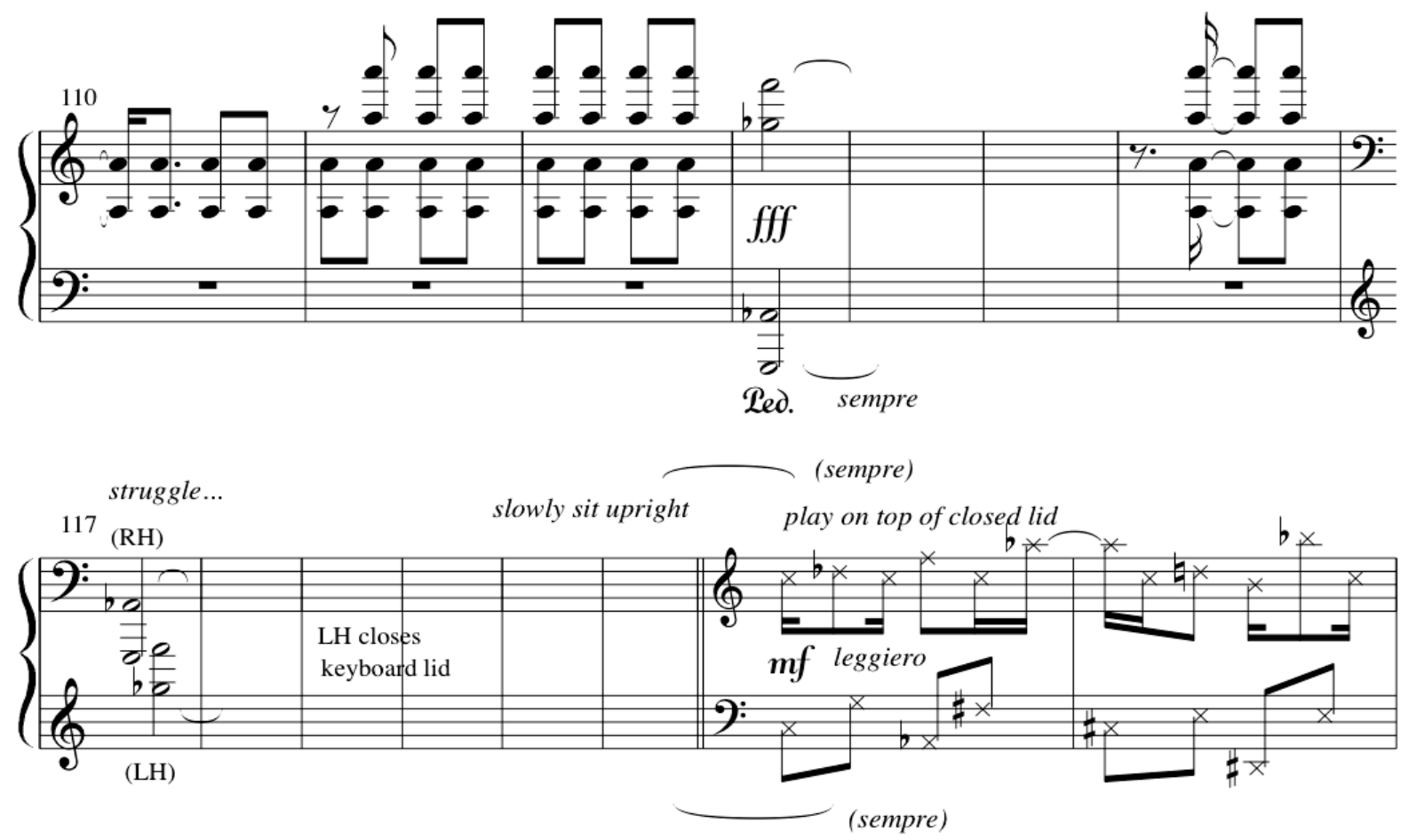

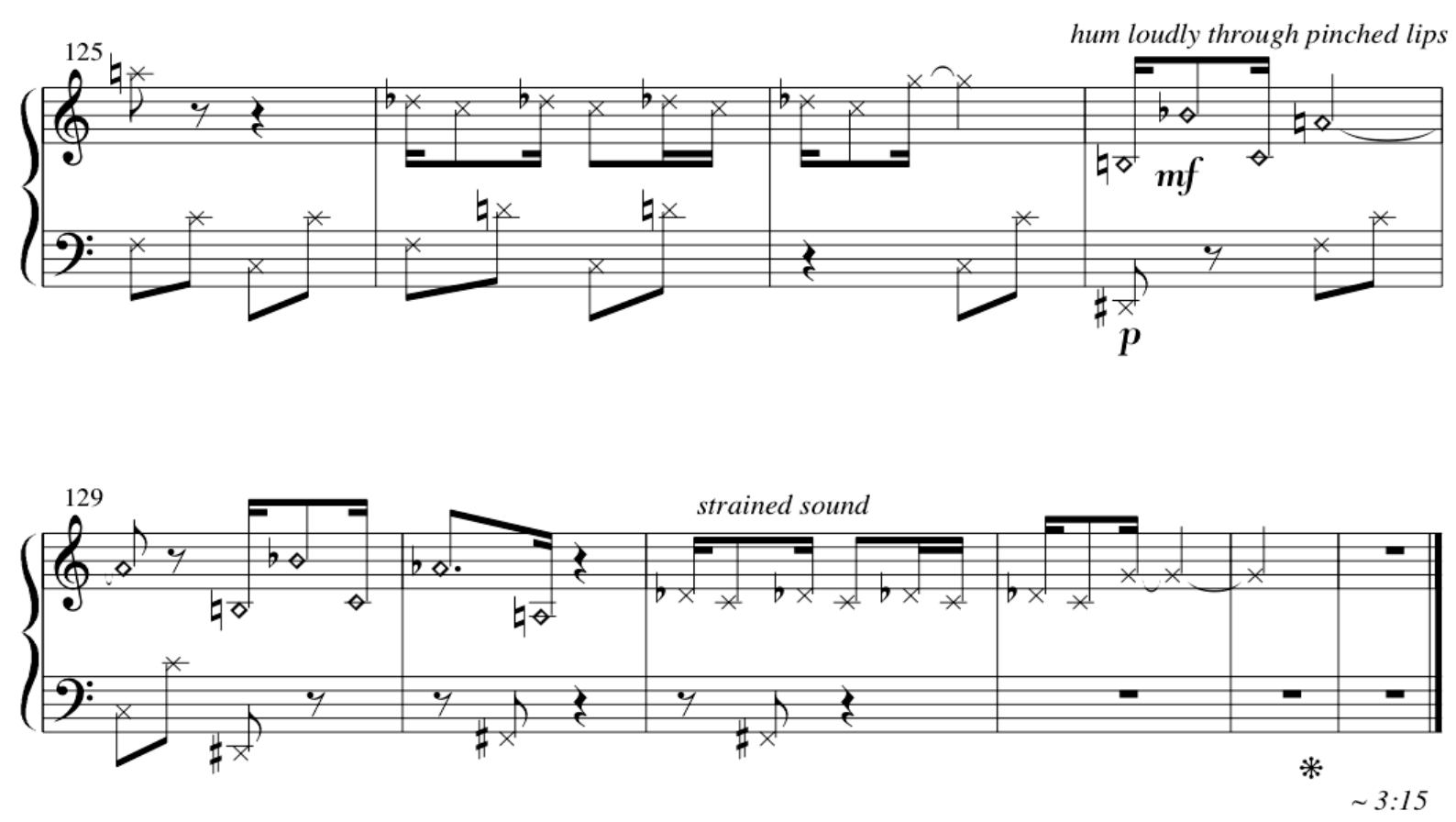

(S. Gavron, director of the 2015 film "Suffragette", unfortunately omitted direct observation of the force-feeding process in her film. Consequently, the audience feels angry witnessing the victim's violent restraining, but not the horror of the invasive process, and so, as with many injustices, we had the privilege to look away).

Delia Derbyshire (1937-2001 UK) was a powerhouse in the BBC Radiophonic Workshop, one of the greatest British exponents of electronic synthesis and musique concrute, although she is mostly known for her electronic arrangement and realisation of Ron Grainer's musical theme for the "Doctor Who" television programme in the 1960s. Despite a high level of music education and mathematics at Cambridge University, and having produced 200 original soundtracks for the Radiophonic workshop, she was considered a studio technician, seldom credited for the work she created.

"Delia Derbyshire", the final piece in this collection of dramatised feminist piano pieces, is scored for piano and fixed media ("tape") playback. It explores sustained ringing sonorities of the live piano alongside a macro-time stretched fragment of piano music from one of D. Derbyshire's own pieces - the opening phrases for the film "Two Houses" (E. Kosmian, 1980) - played through a loudspeaker positioned alongside the piano. The degraded film stock from which the musical fragment was taken affords a strange, lostworld patina: the intonation drifts, the sound quality is grainy, the harmonies have a distinct wobble as though the soundtrack piano had vibrato. The musical fragment was time-stretched to 24 times its original length, and then looped on itself several times. This technique is akin to the physical process that D. Derbyshire had to perform in the studio: recording sounds on 10 or 20 metres of magnetic tape and threading them throughout the studio and even into a corridor before the sonic loop would repeat itself by the tape passing back over the playback head of the tape recorder, which would then be recorded again at a different speed.

D. Derbyshire could "see" the performativity of sound on magnetic tape by the length it occupied, much like A. Hitchcock knew the duration of a shot to be filmed in "The 
Birds" in terms of how many metres of film stock was used (Hitchcock/Truffaut). The core principle of musical sound - time - was thus made material but not specifically fixed until speed of playback was determined, which itself affected the pitch level (among other things) of "performing" the played-back sound recorded on the tape. D. Derbyshire combined her talent in mathematics and musical expression to calculate pitch, speed, length, filtering and rates of change of these physical dimensions of recorded tape sounds to create her compositions, a process parallel to that used by A. Lovelace.

But this combination of talents - the "masculinity" of mathematics and compositional construction with the "femininity" of musical performance and lyrical expression - was considered a gender transgression. Still in the throes of 19thC Victorian aesthetics, British society considered such meddling with suspicion:

"Female creativity was...denied or inhibited by educational and socio-economic pressures born of ideological assumptions. In consequence, many women found them selves marginalized as composers, restricted to 'acceptable' genres such as the drawingroom ballad. Men, too, were affected by the sexual politics of the age, because the supposed revelation of biological truths in music meant that the presence of feminine qualities in their compositions could lead to invidious comparison with the less elevated output of women... . The emotional world was woman's; hence, so was the moral world which was associated with feelings and susceptibilities: 'Let men enjoy in peace and triumph the intellectual kingdom which is theirs,' advised Sarah Lewis in Woman's Mission...'. Because of the fact that the emotional nature in man is less active than in woman,' wrote T.L. Krebs in 1893, "he is superior to her in his ability to penetrate the mysteries of musical theory"'.

The musical content of "Delia Derbyshire" recognises D. Derbyshire's "transgression" by aligning her recorded work as sustained time-stretching with notated fragments of her phrases transcribed for the concert pianist which themselves disintegrate. Since the degraded film soundtrack has a tuning at $\mathrm{A}=428 \mathrm{~Hz}$, there exists a counterpoint of temperaments, tuning and timbre between the recorded piano and the live piano at $\mathrm{A}=$ 440. This means that the live pianist is able to "speak" to the recorded (deceased) pianist, D. Derbyshire herself, using the same material but with a different "dialect" regarding tuning and timing. (To ensure this dialogue, the dynamic levels of the recorded and live pianos are to be the same throughout the performance.)

This musical conversation across the gulf of time, timbre, tuning and articulation can be thought to have a closer kinship between the interlocutors if the pianist was female, if she found her own gendered experiences regarding recognition were parallel to those of D. Derbyshire. The pianist's dialogue is simple, full of silences in order to listen for cues from D. Derbyshire's rich palette. When D. Derbyshire's soundtrack performance of her unprocessed piano arpeggios finally "speak" at 3'43" (her original "voice"), the concert pianist bows out of the conversation and plays a reprise of "Lilith" 's lullaby.

Throughout this collection of five concert hall piano pieces, there is an escalation of visually-confirmed sonic physicality. The spectator sees the pianist's body increasingly extend. "Lilith" demands clustered fingers and palms to make pitch-noise contours. "Ada Lovelace" needs pitch-clusters and loud extreme register fast rhythms as well as unpitched noise with the keys scraped with a stiff card. "Le tombeau de Julia Pastrana" requires knocking and trilling the piano body and the keyboard without producing pitch. "Emmeline Pankhurst" demands impossible arm crossing and hostile assault on the

\footnotetext{
${ }^{1}$ Scott, D. (1994). The Sexual Politics of Victorian Music Aesthetics. Journal of the Royal Musical Association, 119 (1), 91-92.
} 
pianist's hands. "Delia Derbyshire" reduces the pianist's contact with the piano to a bare minimum which leaves the spectator to view each isolated note performed by the pianist as a search for re-integration with the instrument, until finally the piano is effectively removed from the pianist, before returning to the coda of the source, "Lilith".

In 2018, the second collection of dramatised feminist piano pieces will explore further techniques of visually physicalising the nature of pianists' sound production, including tearing the score, performing near-impossible dynamic changes, and being challenged to synchronise with an unreliable recording. As I research further into the gender experiences of women, especially female pianists, additional techniques will emerge.

The question may be asked: Why is a male composer concerned about gendered performance practice with contemporary concert music, especially his own?

The issue is not that men wish women to be deprived of equal rights and opportunities afforded to men. The real reason is that men do not want to lose their privileges which they have given themselves and defended simply by being men. Part of this privilege is to perpetuate systems which are already in place for men when they are born. For example, modern composition bypasses the sonic "social relatedness of human worlds" (which stems from early childhood bonding to parents, especially the mother), to instead create data-based arbitrary rule sets regarding pitch and rhythmic parameters of music. R. Scruton distinguishes between the Authoritarian composer (he cites A. Schoenberg) and the composer with Authority (his example is L. Janáček) when he states, "Schoenberg's approach to music made listening hard. But it made composing easy... .For lesser talents, the adherence to the a priori system failed to conceal the result. Nevertheless, they were fortified against criticism by the erudition of their theory."

Education from a very young age is the only way to fix the imbalance, education supported by unbiased research, as free as possible from culture and tradition. But unfortunately, the events of the past have been written by men for men, making them "His Stories". Education through revered texts such as The Bible perpetuate inequality and guilt: "By woman came sin and therefore death" (Ecclesiasticus 25:24), although this is deftly handled by Elizabeth Cady Stanton in her 1898 work "The Woman's Bible" which exposes the law-driven "priestcraft" oppression of Woman as precipitating the fall of the race, tried, condemned and sentenced without given voice to the initial accusation. And while F. Dostoyevsky refers to systems of servitude and suffering as part of an enforced inequality of the class system in his 1864 novella "Notes from Underground", does this not apply to a global class identity, the female class?

In 2010, Christopher Hitchens stated: "We all know that there is a cure for poverty, a rudimentary one. It does work though. It works everywhere for the same reason. It's colloquially called "the empowerment of women". It's the only thing that does work. If you allow women control over their cycle of reproduction, so they're not chained by their husbands or by village custom to annual animal-type pregnancies, early death, disease - if you will free them from that, $<\ldots . .>$ the whole floor - culturally, socially, medically - of that village will rise"1.

An effective piece of music should be polemical and demonstrate an imperative for its existence. It should have a sense of style(s), be grounded in the craft of communication, sound opinionated and purposeful, and have a real flavour along with nutritious substance.

${ }^{1}$ Hitchens, C. Hitchens-Dembski Debate November 2010. Available at : http://www.youtube.com/watch? $\mathrm{v}=7$ WDloawrRJI\&feature=youtu.be $\# \mathrm{t}=0 \mathrm{~m} 58 \mathrm{~s}$. (Accessed: 16.09 .2017 ). 
The act of performing socio-political music live in front of attentive, active audiences is vital. CDs, DVDs, YouTube, digital dissemination as forms of archiving such performances are only documenting a pale imitation. The actual performance itself is dangerous, physical, has skin which will sweat, is "dirty" by being physical, and the spectator is captive, committed to stay and watch. And think.

The pianist's actions which are imperative in performing " Her Stories Unsung" are outward-facing: these actions themselves look back at the audience to implore each spectator to also take action to achieve gender equality. And if there is memorable music to spur it along, then the effort is less arduous.

In fact, it might even be enjoyable.

"Anyone who tries to make a distinction between education and entertainment doesn't know the first thing about either." (M. McLuhan \& G.B. Leonard ${ }^{1}$ )

"It's misleading to suppose there's any basic difference between education and entertainment. This distinction merely relieves people of the responsibility of looking into the matter" (M. McLuhan²).

"Feminism is a movement to end sexism, sexist exploitation, and oppression...the movement is not about being anti-male. It makes it clear that the problem is sexism. And that clarity helps us remember that all of us, female and male, have been socialized from birth on, to accept sexist thought and action. As a consequence, females can be just as sexist as men... To end patriarchy (another way of naming the institutionalised sexism) we need to be clear that we are all participants in perpetuating sexism...until we let go of sexist thought and action and replace it with feminist thought and action." (B. Hooks ${ }^{3}$ ).

\section{REFEREN CES}

1. Andriessen, L. (1994). "De Staat". (1976). London : Boosey \& Hawkes.

2. Andriessen, L. (2002)."Workers Union"(1975). Amsterdam : Donemus.

3. Bible: The Story of the King James Version, 1611 -2011 (2010). Oxford : Oxford University Press.

4. Dacre, H. "Bicycle Built for Two". London : Francis, Day \& Hunter, 1892.

5. Dostoyevsky, F. (1864). Notes from the underground. London : Epoch and New York:Vintage reprint editions.

6. Fagen, D. "Maxine" from the album "The Nightfly" (Warner Bros 1982).

7. Gavron, S. "Suffragette". Film 4, BFI, Canal+ et al. (UK 2015).

8. Hitchcock, A., Truffaut, F. "Hitchcock: A Definitive Study". (1967) Simon \& Schuster (rev. ed. 1985).

9. Hitchens, C. Hitchens-Dembski Debate November 2010. Available at: www.youtube.com $/$ watch? $\mathrm{v}=7$ WDloawrRJI\&feature=youtu.be $\# \mathrm{t}=0 \mathrm{~m} 58 \mathrm{~s} \quad$ (Accessed: 16.09.2017).

10.Hooks, B. (2000). Feminism is for everybody: passionate politics. Cambridge, MA : South End Press, 123.

\footnotetext{
${ }^{1}$ McLuhan, M., Leonard, G. B. (1967). The future of education: The class of 1989. Look, 21 February, 23-24.

${ }^{2}$ McLuhan, M. (1957). Classroom Without Walls. Explorations, 7; reprinted in Explorations in Communication ed. E. Carpenter \& M. McLuhan.Boston : Beacon, 1960, 19.

${ }^{3}$ Hooks, B. (2000). Feminism is for everybody: passionate politics. Cambridge, MA : South End Press, 1.
} 
11.Kivy, P. (1984). Sound and Semblance: Reflections on Musical Representation. Princeton : Princeton Uni versity Press, 1984. 236 p.

12.Kosmian, E. "Two Houses". Private film collection of Kosmian. (no publisher 1980).

13.Kubrick, S. "2001: A Space Odyssey". Metro-Goldwyn-Meyer (USA 1968).

14.Lynch, D. "The Elephant Man". Brooksfilms (USA 1980).

15.Malone, K. "Her Stories Unsung". (2016). Composers Edition (Chipping Norton UK 2017) ISMN 979-0-5706-8204-1.

16.Malone, K. "Count Me In". (2005) Composers Edition (Chipping Norton UK 2017) ISMN 979-0-5706-8172-3.

17.McLuhan, M. (1957). Classroom Without Walls. Explorations, 7; reprinted in Explorations in Communication ed. E. Carpenter \& M. McLuhan.Boston : Beacon, 1960, 19.

18.McLuhan, M., Leonard, G. B. (1967). The future of education : The class of 1989. Look, 21 February, 23-25.

19.Mrs Pankhurst Arrested. Manchester Guardian, 25 February 1913. Available at : www.theguardian.com/theguardian/1913/feb/25/greatspeeches (Accessed: 16.09.2017).

20.Paganini, N. 24 Caprices for Violin, op. 1. Ricordi (Milan 1818).

21.Reilly, E. (2003). Milestones in Computer Science and Information Technology. Westport, Conn. : Greenwood Press, 380.

22.Rzewski, F. "Les moutons de Panurge". (1969). Scratch Orchestra/Experimental Music Catalogue (London 1971).

23.Schumann, R. "Fantasy Piece" op. 12. (1837) Wiener Urtext/Universal Edition (Vienna 1975).

24.Schumann, R. "Scenes from Childhood", op.15. (1838) C. Henle Verlag (Munich 2007).

25.Schumann, R. (1946). On Music and Musicians. Ed. Konrad Wolff, trans. Paul Rosenfeld. New York : Pantheon, 116.

26.Scott, D. (1994). The Sexual Politics of Victorian Music Aesthetics. Journal of the Royal Musical Association, 119, 1, 91-92.

27.Scruton, R. (2001). True Authority: Janacek, Schoenberg and Us. Reviving the Muse: Essays on Music after Modernism. Ed. Peter Davison. Brinkworth : Claridge Press, 7 30 .

28.Shepherd, J. (1987). Music and Male Hegemony. Music and Society: The Politics of Composition, Performance and reception. Ed. R. Leppert and S. McClary. Cambridge.

29.Silvestrov, V. "Kitsch Music" (1977). Hamburg: M.P. Bellaieff Musikverlag, 2006.

30.Stanton, E. C. (1898). The Woman's Bible. Available at: www.sacredtexts.com/wmn/wb. (Accessed: 16.09.2017).

31.Stravinsky, I. (1936). Chronicle of My Life. London : W. Gollancz, 286.

32.Stravinsky, I. The Rite of Spring. (1913) London : Boosey \& Hawkes, 2000.

Кевін Мелоун. «Ії̈ неоспівані історії»: Фемінізм в музичних творах та концертних програмах. Англо-американський композитор Кевін Мелоун у 2013-2016 роках створив цикл феміністичних фортепіанних композицій як коментар щодо нерівності жінок у патріархальних суспільствах і як заклик до зміни статусу-кво через концертні програми та нові засоби композиції, які мають гендерну специфіку. К. Мелоун, як вимушений переселенець, усвідомив, що маргіналізовані групи піддаються різним типам гніту та нерівності в суспільстві. 
Спираючись на матеріали з США, Великої Британії та України, К. Мелоун разом з аргентинською концертуючою піаністкою Діаною Лопшиц працювали над створенням суспільнополітичної музики, яка вимагає театральної дії під час виконання композиції, а також особливої уваги до гендеру виконавця. Цикл з п'яти фортепіанних композицій присвячений основним аспектам життя п’яти жінок: Ліліт (біблійної жінки, попередниці Сви), Ади Лавлейс, Джулії Пастрана, Еммеліни Панкхурст та Делі Дербішир. Візуально обгрунтоване гендерне кодування концертної музики К. Мелоуна та іiї виконання свідчать про відмову від гендернонейтрального підходу до створення та інтерпретації музичних творів. Таким чином, К. Мелоун закликає композиторів та виконавців підтримувати активістів, які виступають за рівноправність чоловіків та жінок, дотримуючись гендерного балансу в своїй творчості для досягнення цілісності музичного мистецтва (в якому поки що переважає патріархат), бути строгими, але розважливими.

Ключові слова: фемінізм, гендер, фортепіанна музика, соціально-політична музика, театральність, музика Кевіна Мелоуна.

Кевин Мэлоун. «Ее невоспестые истории»: Феминизм в музыкальных произведениях и концертных программах. Англо-американский композитор К. Мэлоун в 20132016 годах создал цикл феминистических фортепианных композиций как комментарий относительно неравенства женщин в патриархальных обществах и как призыв к изменению статуса-кво через концертные программы и новые - гендерно-специфические - средства композиции. Будучи вынужденным переселенцем, К. Мэлоун осознал, що маргинализированные группы подвергаются разным типам угнетения и неравенства в обществе. Опираясь на материалы из США, Великобритании и Украины, К. Мэлоун вместе с аргентинской концертирующей пианисткой Дианой Лопшиц работали над созданием общественно-политической музыки, которая предусматривает театральное действие во время исполнения композиции, при этом особое внимание уделяется гендеру исполнителя. Цикл из пяти фортепианных композиций посвящен основным аспектам жизни пяти женщин: Лилит (предшественницы Евы), Ады Лавлэйс, Джулии Пастрана, Эммелины Панкхурст и Дэли Дэрбишир. Визуальноинформативное гендерное кодирование концертной музыки К. Мэлоуна и ее исполнения свидетельствует об отказе от гендерно-нейтрального подхода к созданию и интерпретации музыкальных произведений. Таким образом К. Мэлоун призывает композиторов и исполнителей поддержать активистов, выступающих за равноправие мужчин и женщин, придерживаясь гендерного баланса в своем творчестве для достижения целостности музыкального искусства (в котором пока царит патриархат), быть строгими, но рассудительными.

Ключевые слова: феминизм, гендер, фортепианная музыка, социально-политическая музыка, театральность, музыка Кевина Мэлоуна.

Стаття надійшла до редакиії 25.10.2017 p. 